\title{
Pseudosmittia fabioi Boggero, Zaupa \& Rossaro, 2014 (Diptera: Chironomidae: Orthocladiinae) a new junior synonym of Prosmittia verae Krasheninnikov \& Makarchenko, 2008
}

\author{
B. Rossaro, ${ }^{1}$ S. Zaupa, ${ }^{2}$ A. Boggero² \\ ${ }^{1}$ Department of Food, Environmental and Nutritional Sciences, University of Milano; \\ ${ }^{2}$ CNR-Institute of Ecosystem Study, Verbania Pallanza (VB), Italy
}

\begin{abstract}
Pseudosmittia fabioi Boggero, Zaupa \& Rossaro, 2014 was found to be conspecific with Prosmittia verae Krasheninnikov \& Makarchenko, 2008 after examination of original description and illustrations. Accordingly, Ps. fabioi is placed in junior synonymy with Pr. verae, new synonymy. The transfer of Ps. fabioi to the genus Prosmittia allows to state that the female of Ps. fabioi (Boggero et al., 2014) is the first description of the female of the genus Prosmittia.
\end{abstract}

\section{Introduction}

Recently Eugenji Makarchenko sent to the senior author a paper in Cyrillic, with English diagnosis, describing a new species belonging to the genus Prosmittia Brundin, 1956: Prosmittia verae Krasheninnikov \& Makarchenko, 2008. From an examination of the drawings it was

Correspondence: Bruno Rossaro, DeFENS Department of Food, Environmental and Nutritional Sciences, Università degli Studi di Milano, via Celoria 2, I 20133 Milano, Italy.

E-mail: bruno.rossaro@unimi.it

Key words: Synonymy; Chironomidae; Orthocladiinae; Prosmittia; Pseudosmittia.

Acknowledgments: a particular thank go to Martin Spies (Staatliche Naturwissenschaftliche Sammlungen Bayerns Zoologische Staatssammlung München, Germany) and Eugenji Makarchenko (Institute of Biology and Soil Sciences, Far East Branch of Russian Academy of Sciences, Vladivostok), for the precious information given, essential to establish the synonymy.

Received for publication: 12 March 2015.

Revision received: 29 April 2015.

Accepted for publication: 10 June 2015.

(C) Copyright B. Rossaro et al., 2015

Licensee PAGEPress, Italy

Journal of Entomological and Acarological Research 2015; 47:5151

doi:10.4081/jear.2015.5151

This article is distributed under the terms of the Creative Commons Attribution Noncommercial License (by-nc 3.0) which permits any noncommercial use, distribution, and reproduction in any medium, provided the original author(s) and source are credited. immediately apparent that the described species is identical with Pseudosmittia fabioi, Boggero, Zaupa \& Rossaro, 2014. The apparent synonymy was confirmed after an accurate examination of the original description given in Cyrillic and kindly translated by Martin Spies.

The genus Prosmittia was established by Brundin (1956) for Pseudosmittia jemtlandica Brundin, 1947; Cranston \& Oliver (1988) synonymized Prosmittia with Pseudosmittia Goetghebuer, 1933, but Sæther \& Ferrington (1993) reestablished the Prosmittia genus because of a unique combination of characters, separating it from Pseudosmittia, that is the lack of acrostichals, a moderate costal extension, $\mathrm{R}_{4+5}$ ending near to the wing apex, distal to $\mathrm{M}_{3+4}$. The genus includes 15 Palaearctic species (Ashe \& 0'Connor, 2012), three of these, Pr. jemtlandica Brundin, 1947, Pr. rectangularis Tuiskunen, 1985, Pr. valentinae, Baranov, 2011, have been known from Europe (Sæther et al., 2000), one, Pr. verae Krashennikov \& Makarchenko, 2008 from Caucasus, nine, Pr. furudoseptima (Sasa \& Arakawa, 1994), Pr. hibaraundecima (Sasa \& Suzuki, 1998), Pr. itachituberculata (Sasa \& Kawai, 1987), Pr. itachinidiocura (Sasa \& Kawai, 1987), Pr. kamiquarta (Sasa \& Hirabayashi, 1991), P. kibaprima (Sasa \& Sumita, 2001) Pr. taishodeea (Sasa \& Tanaka, 2001), Pr. togacurva (Sasa \& Okazawa, 1992) and Pr. yakitaira (Sasa \& Suzuki, 2000) from Japan, two, Pr. tauiensis Makarchenko \& Makarchenko, 2007 and Pr. anyuiica Makarchenko \& Makarchenko, 2009, are known from Russian Far East.

Females, pupae and larvae of all the known species were until now unknown. On the basis of the present synonymy it appears that the female of Prosmittia is described in Boggero et al. (2014).

The present paper formally establishes the synonymy between $\mathrm{Pr}$. verae and Ps. fabioi allowing to extend the distribution of the Pr. verae to the Mediterranean area.

The terminology and abbreviations used in the description follow Sæther (1980).

\section{Prosmittia verae Krasheninnikov \& Makarchenko, 2008}

Prosmittia verae Krasheninnikov \& Makarchenko, 2008: 359 (original description).

Pseudosmittia fabioi Boggero, Zaupa \& Rossaro, 2014: 1 (original description). Syn. nov.

\section{Description}

A complete description of the species is in Krasheninnikov \& Makarchenko (2008) and in Boggero et al. (2014). Comparisons of measurements on Pr. verae and Ps. fabioi are given in Table 1 (head, body, wings) and Table 2 (legs).

Here are summarized the characters supporting the inclusion of the species in Prosmittia and the synonymy of the two species. 
Wing costal vein extending beyond tip of $\mathrm{R}_{4+5}$ by less than $50 \mu \mathrm{m}$; all veins without setae. $\mathrm{R}_{4+5}$ distal with respect to $\mathrm{M}_{3+4}$, vein $\mathrm{Cu}_{1}$ curved, sinusoidal, anal lobe reduced, alula and squama bare.

Hypopygium. Tergite IX with 12-14 setae, with narrow, rounded-triangular and microtrichia-covered anal point 35-46 $\mu \mathrm{m}$ long. Laterosternite IX with 2-3 setae. Gonocoxite 165-176 $\mu$ m long, dorsal part of inferior volsella bare, fingerlike, ventral part long, rounded, covered with short setae. Gonostylus 57-66 $\mu \mathrm{m}$ long, covered with setae, subapically narrowed, distally on outer edge with angular projection about 7-8 $\mu \mathrm{m}$ long; macroseta 10-11 $\mu \mathrm{m}$ long. Transverse sternapodeme 94-16 $\mu \mathrm{m}$ long, lateral projections reduced. Virga small, forming one spine 17-24 $\mu \mathrm{m}$ in length. Hypopygium ratio: ratio of length of gonocoxyte to length of gonostylus 2.67-2.96.

\section{Distribution}

Pr. verae was known only from the type locality on the Agura river at the foot of Little Akhun (North Caucasus), now its distribution is extended to the Mediterranean area in Sardinia (Boggero et al., 2014).

\section{Discussion and conclusions}

The inclusion of the genus Prosmittia in Pseudosmittia (Cranston \& Oliver, 1988) had the effect that in the holarctic key of genera (Cranston et al., 1989) Prosmittia was not included, so Boggero et al. (2014), ignoring Sæther \& Ferrington (1993), Sæther et al. (2000) and

Table 1. Range of lengths (in mm or $\mu \mathrm{m}$ ) and proportions of segments in Prosmittia verae and Pseudosmittia fabioi.

\begin{tabular}{lcc} 
& Pr. verae $(\mathbf{n = 3})$ & Ps. fabioi (n=10) \\
Body color & Brown & Brownish-black \\
Body length & $2.3-2.4 \mathrm{~mm}$ & $2.3-2.6 \mathrm{~mm}$ \\
\hline Wing length & $1.7-2.0 \mathrm{~mm}$ & $1.5-1.7 \mathrm{~mm}$ \\
Body length/wing length & 1.5 & 1.53 \\
\hline Vertical setae & $3-5$ & $3-6$ \\
Postorbital setae & $2-5$ & $4-5$ \\
\hline Clypeals & 6 & 6 \\
Length of terminal flagellomere & $346-468 \mu \mathrm{m}$ & $364-368 \mu \mathrm{m}$ \\
\hline AR & $0.76-0.94$ & $0.80-0.86$ \\
Palpomere lengths & $22-24 ; 33-47 ; 83-110 ; 70-94 ; 94-138$ & $420-428 \mu \mathrm{m}$ \\
\hline Head wide & $380-413 \mu \mathrm{m}$ & $5-7$ \\
Dorsocentrals & $7-9$ & $22-24 ; 44-45 ; 91-93 ; 78-80 ; 92-94$ \\
\hline Acrostichals & 0 & 3 \\
Prealars & 3 & $4-8$ \\
\hline Scutellars & 4 & 1.38 \\
VR & 1.43 & 3 \\
\hline
\end{tabular}

Table 2. Range of lengths (in $\mu \mathrm{m}$ ) and proportions of segments in Prosmittia verae and Pseudosmittia fabioi (male, $n=3$ ).

\begin{tabular}{|c|c|c|c|c|c|}
\hline P. verae & fe & ti & $\mathrm{ta}_{1}$ & $\mathrm{ta}_{2}$ & $\mathrm{ta}_{3}$ \\
\hline $\begin{array}{l}\text { P1 } \\
\text { P2 } \\
\text { P3 }\end{array}$ & $\begin{array}{l}517-605 \\
545-671 \\
589-660\end{array}$ & $\begin{array}{l}605-748 \\
578-677 \\
616-776\end{array}$ & $\begin{array}{l}292-363 \\
259-325 \\
314-418\end{array}$ & $\begin{array}{l}204-264 \\
171-209 \\
176-242\end{array}$ & $\begin{array}{l}116-127 \\
110-127 \\
160-198\end{array}$ \\
\hline & $\mathrm{ta}_{4}$ & $\mathrm{ta}_{5}$ & LR & BV & SV \\
\hline $\begin{array}{l}\text { P1 } \\
\text { P2 } \\
\text { P3 }\end{array}$ & $\begin{array}{l}55-66 \\
50-55 \\
61-72\end{array}$ & $\begin{array}{l}50-61 \\
49-55 \\
55-61\end{array}$ & $\begin{array}{l}0.45-0.49 \\
0.45-0.48 \\
0.51-0.54\end{array}$ & $\begin{array}{l}3.26-3.39 \\
3.64-3.75 \\
3.24-3.36\end{array}$ & $\begin{array}{l}3.73-3.98 \\
4.15-4.35 \\
3.43-3.84\end{array}$ \\
\hline P. fabioi & $\mathrm{fe}$ & ti & $\operatorname{ta}_{1}$ & $\mathrm{ta}_{2}$ & $\mathrm{ta}_{3}$ \\
\hline $\begin{array}{l}\text { P1 } \\
\text { P2 } \\
\text { P3 } \\
\end{array}$ & $\begin{array}{l}530-564 \\
572-598 \\
586-604\end{array}$ & $\begin{array}{l}636-664 \\
577-603 \\
649-683 \\
\end{array}$ & $\begin{array}{l}294-318 \\
265-277 \\
335-361\end{array}$ & $\begin{array}{l}212-226 \\
175-179 \\
204-210\end{array}$ & $\begin{array}{l}122-128 \\
109-121 \\
167-179 \\
\end{array}$ \\
\hline & $\mathrm{ta}_{4}$ & $\mathrm{ta}^{5}$ & LR & BV & SV \\
\hline $\begin{array}{l}\text { P1 } \\
\text { P2 } \\
\text { P3 }\end{array}$ & $\begin{array}{l}59-63 \\
43-49 \\
54-64\end{array}$ & $\begin{array}{l}60-62 \\
56-58 \\
52-54\end{array}$ & $\begin{array}{l}0.46-0.48 \\
0.46-0.46 \\
0.52-0.53\end{array}$ & $\begin{array}{l}3.22-3.23 \\
3.69-3.63 \\
3.29-3.25\end{array}$ & $\begin{array}{l}3.97-3.86 \\
4.34-4.34 \\
3.69-3.57\end{array}$ \\
\hline
\end{tabular}

fe, femur; ti, tibia; ta1-5, tarsomeres 1-5; LR, leg ratio, ratio of metatarsus to tibia; BV, Beinverhältnisse, combined length of femur, tibia, and basitarsus (tal) divided by combined length of tarsomeres 2-5; SV, SchenkelScheine-verhältnis, ratio of femur plus tibia to metatarsus $\left(\operatorname{ta}_{1}\right)$. 
overlooking the presence of a wing costal extension, were erroneously induced to include Ps. fabioi in the genus Pseudosmittia. The discovering of Pr. verae description (Krasheninnikov \& Makarchenko, 2008) and a careful subsequent reexamination of Ps. fabioi allowed to conclude that Ps. fabioi, with a moderate costal extension, $\mathrm{R}_{4+5}$ ending distal to $\mathrm{M}_{3+4}$ and absence of acrostichals, can be included beyond any doubt in the genus Prosmittia; the shape of hypopygium emphasized the strict similarity with the one of Pr. verae. The small differences observed in morphometric characters can be reasonably interpreted as differences between populations of the same species in different areas. The lack of acrostichals resolves also the question about the presence or absence of acrostichals in Pseudosmittia (Boggero et al., 2014): the present results allow confirming that acrostichals are present in all Pseudosmittia (Ferrington \& Sæther, 2000 or 2011) and absent in all Prosmittia. Another consequence of the transfer of Ps. fabioi from Pseudosmittia to Prosmittia is that the description of female of PS. fabioi is the first description of female belonging to the genus Prosmittia; in Prosmittia the female antenna is characterized by six antennal flagellomeres, adding an additional character in a generic separation of Prosmittia from Pseudosmittia, because all the species of Pseudosmittia of which females are described possess only five antennal flagellomeres.

\section{References}

ASHE P., O'CONNOR J.P., 2012 - A World Catalogue of Chironomidae (Diptera). Part 2. Orthocladiinae. - Irish Biogeographical Society and National Museum of Ireland, Dublin. xvi+968 pp.

BOGGER0 A., ZAUPA S., ROSSARO B., 2014 - Pseudosmittia fabioi sp. n., a new species from Sardinia (Diptera, Chironomidae, Orthocladiinae). - J. Entomol. Acarol. Res. 46: 1-5.

BRUNDIN L., 1947 - Zur Kenntnis der schwedischen Chironomiden Arkiv Zool. Bd. 39A. Hf. 3: 1-95.

BRUNDIN L., 1956 - Zur Systematik der Orthocladiinae (Diptera, Chironomidae) - Rep. Inst. Freshwater Res. Drottningholm. 37: 5-185.

CRANSTON P.S., OLIVER D.R., 1988 - Additions and corrections to the nearctic Orthocladiinae (Diptera, Chironomidae). - Can Entomol. 120: 425-462.

CRANSTON P.S., OLIVER D.R., SÆTHER O.A., 1989 - The adult males of Orthocladiinae (Diptera: Chironomidae) of the Holarctic region. Keys and diagnoses. - In WIEDERHOLM T. (Ed.), Chironomidae of the Holarctic region. Part 3. Adult males. - Entomol. Scand. Suppl. 34: $165-352$.

FERRINGTON L.C., SÆTHER 0.A., 2011 - A revision of the genera Pseudosmittia Edwards, 1932, Allocladius Kieffer, 1913, and Hydrosmittia gen. n. (Diptera: Chironomidae, Orthocladiinae). Zootaxa 2849: 1-314.

KRASHENINNIKOV A.B., MAKARCHENKO E. A., 2008 - Prosmittia verae sp. n., a new chironomid species (Diptera:Chironomidae: Orthocladiinae) from the environs of Sochi Town (the Northern Caucasus). - Caucasian Entomol. Bull. 4: 359-361.

SÆTHER O.A., 1980 - Glossary of chironomid morphology terminology (Diptera: Chironomidae). - Entomol. Scand. Suppl. 14: 1-51.

SÆTHER 0.A., ASHE P., MURRAY D.A., 2000 - Family Chironomidae. Papp L. and Darvas B. (Eds), Contributions to a Manual of Palaearctic Diptera (with special reference to the flies of economic importance). - Science Herald, Budapest. 4. A.6.: 113-334.

SÆTHER 0.A., FERRINGTON L., 1993 - Redescription of Prosmittia jemtlandica (Brundin, 1947), with a review of the genus. - J. Kans. Ent. Soc. 66: 257-262. 